\title{
Antimicrobial Activity of Bee Pollen Ethanolic and Methanolic Extracts on Staphylococcus aureus Bacterial Strain
}

\author{
RodicA MĂRGĂOAN ${ }^{1}$, Liviu AL. MĂRGHITAŞ ${ }^{1}$, Daniel S. DEZMIREAN ${ }^{1 *}$, Bogdan GHERMAN ${ }^{1}$, Flore \\ CHIRILA ${ }^{2}$, Iulia ZACHARIAS ${ }^{1}$,Otilia BOBIŞ ${ }^{1}$ \\ ${ }^{1)}$ Department of Apiculture and Sericulture, University of Agricultural Sciences and Veterinary \\ Medicine Cluj-Napoca, Romania \\ ${ }^{2)}$ Department of Microbiology (Veterinary Medicine), University of Agricultural Sciences and Veterinary \\ Medicine Cluj-Napoca, Romania. \\ *Corresponding author, email: ddezmirean@usamvcluj.ro
}

Bulletin UASVM Animal Science and Biotechnologies 72(1) / 2015

Print ISSN 1843-5262; Electronic ISSN 1843-536X

DOI:10.15835/buasvmcn-asb:10791

\begin{abstract}
Bee pollen is consumed for api-therapeutical, nutritional and medicinal properties. Its actions are attributed to its chemical composition and mostly phenolics, carotenoids, fatty acids and vitamins. For this study, bee pollen was freshly harvested and immediately placed at $-18^{\circ} \mathrm{C}$. Two different extraction solvents were used: ethanol and methanol, in three different dilutions $(60,70,80 \%) .5 \%, 10 \%$ and $15 \%$ pollen concentrations in each solvent solution were carried out to determine the most efficient variant, possessing the highest antibacterial activity, using the disc diffusion method. Stock culture of Staphylococcus aureus bacteria was grown in Nutrient Broth at $37^{\circ} \mathrm{C}$ for $24 \mathrm{~h}$ in a shaker. The inhibition zones were different, according to the extraction solvent used and also the pollen concentration. Methanol extract (70\%) of $15 \%$ pollen has the biggest inhibition diameter. Negative controls (methanol and ethanol) did not show an inhibitory effect on the tested bacteria, while positive control (Streptomycin) has the highest antimicrobial activity.
\end{abstract}

Keywords: antimicrobial activity, bee pollen, ethanol extract, methanol extract

\section{INTRODUCTION}

Numerous studies have shown that aromatic and medicinal plants are sources of diverse nutrient and non-nutrient molecules, many of which display antioxidant and antimicrobial properties, which can protect the human body against both cellular oxidation reactions and pathogens (Senguel et al., 2009).

Bee pollen is the result of the agglutination of flower pollens, carried out by worker honey bees, with nectar (and/or honey) and salivary substances, collected at the hive entrance and used as food for all the developmental stages in the hive (Campos et al. 2008).

Bee pollen is known for its therapeutic properties attributed to several compounds, such as minerals, vitamins, essential amino acids, fatty acids, carotenoids, phenolics (Human et. al., 2006), and is consumed for its nutritional and medicinal properties (Abouda et al., 2011). The therapeutic action of this hive product has been related to several phenolics compounds, such as flavonol glycoside and hydroxycinnamic acids (Campos et al., 1997) with antioxidant activity. 
The bioactive compounds can be extracted using a suitable solvent (Carpes et al. 2007).

Methanol extracts used for antimicrobial activity determination on different bacterial strains causing animal and vegetal pathology were studied by Basim et al. (2006), Graikou et al. (2011), Morais et al. (2011) or Pascoal et al., (2014).

Carpes et al. (2007) used, for bee pollen extraction, ethanol 40,50, 60, 70, 80 and $90 \%$ and the best antibacterial activity was obtained for bee pollen extract with $70 \%$ ethanol.

The aim of this study was the in vitro testing of different extraction solvents (methanol, ethanol) for bee pollen, against Staphylococcus aureus bacterial strain.

\section{MATERIALS AND METHODS}

Bee pollen was freshly harvested and immediately placed at $-18^{\circ} \mathrm{C}$. Two different extraction solvents were used (ethanol and methanol) in three different dilutions $(60,70$, $80 \%$ ). $5 \%, 10 \%$ and $15 \%$ pollen concentration in each solvent solution were carried out to determine the most efficient variant, possessing the highest antibacterial activity.

Extract preparation. Different amounts of bee pollen were milled, homogenized and individually extracted with $10 \mathrm{ml}$ of methanol and ethanol 60,70 and $80 \%(\mathrm{v} / \mathrm{v})$ at room temperature for $1 \mathrm{~h}$. After sonication (15min), maceration and filtration (Mărghitaş et al., 2009), the resulting solutions were stored at $4{ }^{\circ} \mathrm{C}$ until antibacterial activity determination.
Microbiological cultures. Gram positive bacterial strain Staphylococcus aureus ATCC $6538 \mathrm{P}$ were used for experiments. Stock culture of Staphylococcus aureus bacteria was grown in Nutrient Broth at $37^{\circ} \mathrm{C}$ for $24 \mathrm{~h}$ in a shaker.

Testing sensitivity of microorganism to antibiotics was performed by disc diffusion method (Collins et al., 1995), using Streptomycin (S) H-1141 $(10 \mu \mathrm{g} /$ microtablets $)$, Biolab Zrt. Budapest as a positive control. The bacterial suspension $(10 \mu \mathrm{l})$ was inoculated into MuellerHinton agar plate (Scharlau Chemie SA Barcelona, Spain). The antibiotic was placed aseptically in the middle of the plate and was incubated at $37^{\circ} \mathrm{C}$ for $24 \mathrm{~h}$. The inhibitory zone diameter was measured in $\mathrm{mm}$.

Antibacterial activity of pollen was studied also by disc diffusion method (Collins et al., 1995). The inoculum suspension was prepared at a concentration of 0.5 MacFarland scale, confirmed by spectrophotometric reading at $580 \mathrm{~nm}$. The bacterial suspension $(10 \mu \mathrm{l})$ was inoculated into Mueller-Hinton agar plate. Aliquots of $40 \mu$ bee pollen solutions were applied on paper disk and placed in plates with active culture. The negative control was $40 \mu \mathrm{l}$ of ethanol and methanol.

\section{RESULTS AND DISCUSSION}

The inhibition zones were different, according to the extraction solvent used and also the pollen concentration. Methanol extract (70\%) of $15 \%$ pollen has the biggest inhibition diameter. Negative controls (methanol and ethanol) did not show an inhibitory effect on the tested bacteria,

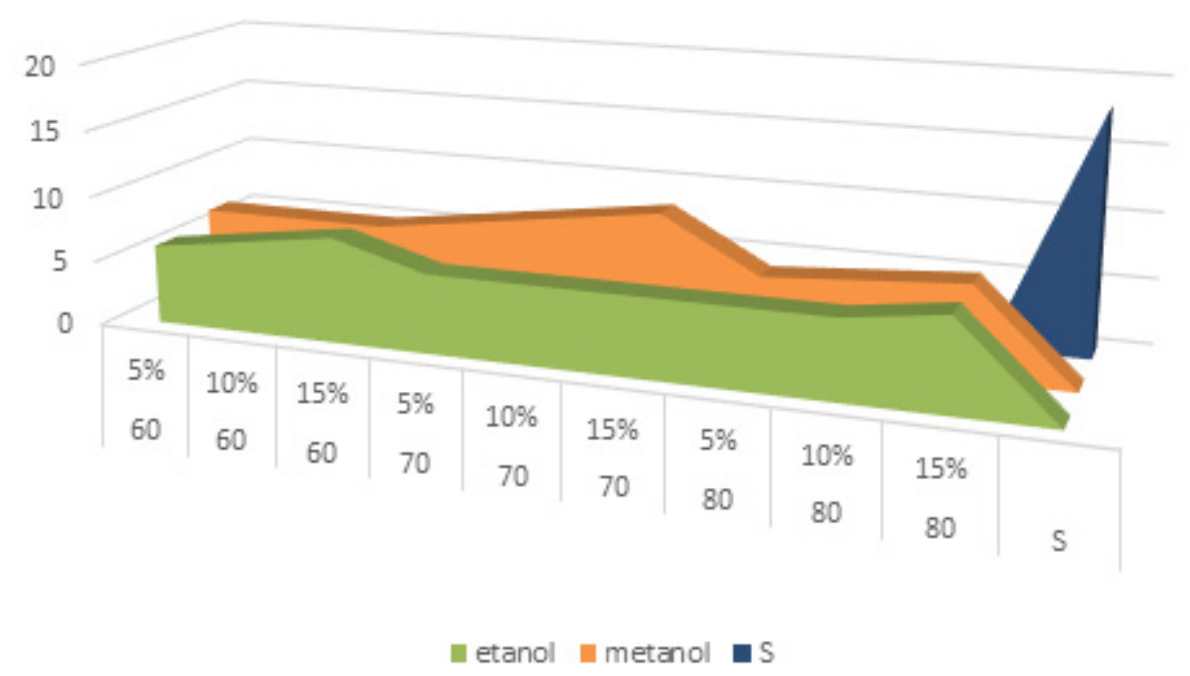

Fig. 1. Inhibition zones (mm) of ethanol, methanol extract and Streptomycin 
Staphylococcus aureus, while positive control (Streptomycin) has the highest antimicrobial activity (Fig. 1).

Bee pollen constitutes a good source of healthy compounds, namely phenolics. This product is a potential source of antimicrobial agents since an increasing number of bacteria are developing resistance to antibiotics, extracts of bee pollen hold great promise for novel medicine in our time (Morais et al., 2011).

According to literature reviews, concentration of phenolic compounds does not determine entirely the antibacterial activity, but the nature of phenolic compounds present in extracts (Carpes et al., 2007).

Different extracts exhibited different antioxidant and antibacterial activities. Bee pollen seems to have interesting biological properties and can be considered as a functional food (Carpes et al., 2007).

\section{CONCLUSION}

In the present research work, we concluded that the methanol extract $70 \%$ with $15 \%$ bee pollen concentration presents the highest inhibition zone.

Acknowledgments. This research was carried out through the Partnerships in Priority Areas Programme-PN II, developed with the support of MEN-UEFISCDI, project no. 148/2014.

\section{REFERENCES}

1. Abouda Z, Zerdani I, Kalalou I, Faid M, Ahami MT (2011). The antibacterial activity of Maroccan bee bread and bee-pollen (fresh and dried) against pathogenic bacteria. Research Journal of Microbiology 6(4): 376-384.

2. Carpes ST, Begnini R, Alencar SM, Masson ML (2007). Study of preparation of bee pollen extracts, antioxidant and antibacterial activity. Cienc.Agrotec. 31(6): 18181825.

3. Campos, MGR, Bogdanov S, Almeida-Muradian LB, Szczesna T, Mancebo Y, Frigerio C, Ferreira F (2008). Pollen composition and standardization of analytical methods. 47(2):156-163.

4. Mărghitas, LAL, Stanciu OG, Dezmirean DS, Bobiș O, Popescu O, Bogdanov S, Campos MG (2009). In vitro antioxidant capacity of honeybee-collected pollen of selected floral origin harvested from Romania. Food Chemistry. 115:878-883.

5. Senguel M, Yildiz H, Gungor N, Cetin B, Eser Z, Ercisli $S$ (2009). Total phenolic content, antioxidant and antimicrobial activities of some medicinal plants. Pak J Pharm Sci. 22(1):102-106.

6. Morais M, Moreira L, Feas X, Estevinho LM (2011). Honeybee-collected pollen from five Portuguese natural Parks: Palynological origin, phenolic content, antioxidant properties and antimicrobial activity. Food Chem Toxicol. 49: 1096-1101.

7. Human H, Nicolson SW (2006). Nutritional content of fresh, bee-collected and stored pollen of Aloe greatheadii var. davyana (Asphodelaceae). Phytochemistry. 67:14861492.

8. Graikou K, Kapeta S, Aligiannis N, Sotiroudis G, Chondrogianni N, Gonos E, Chinou I (2011). Chemical analysis of Greek pollen-Antioxidant, antimicrobial and proteasome activation properties. J Chemistry Central. 5:33-41.

9. Pascoal A, Rodrigues S, Teixeira A, Feas X, Estevinho LM (2014). Biological activites of commercial bee pollens: Antimicrobial, antimutagenic, antioxidant and antiinflamatory. Food and Chemical Toxicology. 63:233-239.

10. Campos MG, Markham KR, Mitchell KA, Proenca da Cunha A (1997). An approach to the characterization of bee pollen via their flavonoid/phenolic profiles. Phytochem Anal. 8:181-185.

11. Basim E, Basim H, Ozcan M (2006). Antibacterial activities of Turkish pollen and propolis extracts against plant bacterial pathogens. J Food Engineering. 77:992-996.

12. Collins CH, Lyne PM, Grange JM (1995). Collins and Lynes Microbiological Methods. $7^{\text {th }}$ Edn. Butterworth. Heinman Oxford. pp.493. 